\title{
Romatoit Artritte Hastalık Aktivitesinin Nötrofil Lenfosit Oranı ve Ortalama Trombosit Hacmi ile İlişkisi
}

\section{Relation of Disease Severity with Mean Platelet Volume and Neutrophil Lymphocyte Ratio in Rheumatoid Arthritis}

\author{
Gökhan AYTEKIN ${ }^{1}$, İbrahim AKDAĞ $\breve{~}^{2}$
}

$1 \mathrm{MD}$, Specialist in Internal Medicine, Fellow in Training in Allergy and Clinical Immunology, Necmettin Erbakan University, Meram Faculty of Medicine, KONYA

2 MD, Associate Professor in Internal Medicine and Nephrology, Dışkapı Yıldırım Beyazıt Education and Research Hospital, ANKARA

\section{Öz}

Amaç: Romatoid Artrit (RA), simetrik eroziv sinovit ile karakterize, kronik sistemik inflamatuvar bir hastalıktır. Nötrofil lenfosit oranı (NLO) ve ortalama trombosit hacmi (OTH) ise inflamasyonun şiddetini belirlemek için kullanılan yeni belirteçlerdir. Biz bu çalışma ile RA'de hastalık aktivitesi ile NLO ve OTH değerleri arasındaki ilişkiyi ortaya koymayı amaçladık.

Gereç ve Yöntemler: Bu retrospektif çalışma Mart 2012 ile Mart 2013 arasında yapıldı. Çalışmaya toplam 156 RA hastası dahil edildi.

Bulgular: NLO aktif hastalı grubunda remisyon grubuna göre daha yüksekti, ancak remisyon grubu ile aktif hastalı grubu arasında anlamlı fark yoktu (p: 0.616). Düşük hastalık aktivitesi grubunda, orta derecede hastalık aktivitesi grubunda ve yüksek hastalık aktivite grubunda NLO sirasiyla $1.98 \pm 0.71,2.26 \pm 1.04$ ve $3.11 \pm$ 2.16 idi. Karşılaştırılan gruplar arasında istatiksel olarak anlamlı fark mevcuttu (p: 0.030). Remisyon grubu ve aktif hastalık grubunun OTH değerleri sırasıyla $8.54 \pm 0.78$ ve $8.89 \pm 0.99 \mathrm{fl}$ idi ve gruplar arasında anlamlı fark yoktu (p: 0.126). Ayrıca remisyon grubu, düşük hastalık aktivite grubu, orta hastalık aktivite grubu ve yüksek hastalık aktivite grubunda OTH sirasiyla $9.31 \pm 1.09,8.91 \pm 0.98,8.71 \pm 0.97 \mathrm{fl}$ idi. Daha yüksek hastalık aktivitesi olan hastalarda OTH azalmasına rağmen, gruplar arasında anlamlı fark mevcut değildi (p: 0.206).

Sonuç: NLO, RA hastalarında hastalık aktivitesini değerlendirmek için faydalı bir belirteçtir. Artan NLO değerleri artmış hastalık aktivitesine işaret eder. Fakat OTH değerlerinin RA hastalarında hastalık aktivite göstergesi olarak kullanılabilmesi için daha kapsamlı çalışmalara ihtiyaç vardır.

Anahtar Kelimeler: Nötrofil lenfosit Oranı,Ortalama Trombosit Hacmi,Romatoit Artrit

\section{INTRODUCTION}

Rheumatoid arthritis (RA) is a systemic inflammatory disease characterized by symmetrical erosive synovitis. It can be seen in all races and ethnic groups. Rheumatoid arthritis can cause widespread and permanent sequelae and morbidity, if not treated at an early stage(1). Previous studies have shown that rheumatoid arthritis is closely related to prolonged inflammation and inflammation markers such as and C-reactive protein (CRP), sedimentation rate $(2,3)$.

\begin{tabular}{|c|c|}
\hline İletişim: & $\begin{array}{l}\text { : Dr. Gökhan AYTEKIN, Necmettin Erbakan Üniversi- } \\
\text { tesi, Meram Tıp Fakültesi,İç Hastalıkları AD, Allergi ve } \\
\text { Klinik İmmünoloji Bilim Dalı, Konya }\end{array}$ \\
\hline DOI: & 10.17517/ksutfd.512962 \\
\hline
\end{tabular}

\section{Abstract}

Objective: Rheumatoid arthritis (RA) is a systemic inflammatory disease characterized by symmetrical erosive synovitis. The neutrophil to lymphocyte ratio (NLR) and mean platelet volume (MPV) have been widely used to determine the severity of inflammation. Objectives: We aimed to investigate NLR and MPV values in RA population further assessing the relation between these indices, inflammatory markers and disease activity scores.

Material and Methods: The present study was performed between March 2012 and March 2013, and designed retrospectively. Total 156 patients of RA were included.

Results: The NLR was higher in active disease group but there was not significant difference between the remission group and active disease group (p: 0.616). Also NLR of low disease activity group, moderate disease activity group and high disease activity group were $1.98 \pm 0.71,2.26 \pm 1.04$, and $3.11 \pm 2.16$ respectively. There is significant difference between groups (p: 0.030 ). The MPV of remission group and active disease group were $8.54 \pm 0.78 \mathrm{fl}$ and $8.89 \pm 0.99 \mathrm{fl}$, respectively and there is no significant difference between both groups ( $\mathrm{p}$ : 0.126). Also the MPV of remission group, low disease activity group, moderate disease activity group and high disease activity group were $9.31 \pm 1.09 \mathrm{fl}, 8.91 \pm 0.98 \mathrm{fl}, 8.71 \pm 0.97 \mathrm{fl}$, respectively. Although MPV is reduced in patients with higher disease activity, it was found that there was no significant difference between the groups (p: 0.206).

Conclusions: NLR can be a useful marker to assess disease activity in RA patients. Increased NLR values may indicate increased disease activity. Whereas, there is a need for comprehensive studies to claim that average platelet volume as an indicator of disease severity in RA patients.

Key Words: Neutrophil Lymphocyte Ratio,Mean Platelet Volume,Rheumatoid Arthritis

Simple and easily available parameters such as neutrophil-lymphocyte ratio (NLR) and mean platelet volume (MPV) obtained from hemogram results are used to demonstrate the prevalence of inflammation in conditions such as cardiovascular diseases, malignancies, diabetes mellitus, hypertension and auto-inflammatory diseases (4-8). Unfortunately, studies on NLR in rheumatoid arthritis, a disease characterized by diffuse inflammation, are limited. In the studies investigating the relationship between MPV and rheumatoid arthritis, the reported results are conflicting $(9,10)$. 
In this study, we aimed to determine the relationship between disease activity scores, which are the indications of disease activity, inflammatory parameters and inflammatory indicators such as NLR and MPV.

\section{MATERIAL AND METHODS}

\section{Study Population}

Between March 2012 and March 2013, 156 rheumatoid arthritis patients, admitted to Dışkapı Yıldırım Beyazıt Training and Research Hospital Internal Medicine and Rheumatology polyclinics, were retrospectively analyzed. American College of Rheumatology criteria were used for the diagnosis of rheumatoid arthritis (11). Patients with coronary artery disease, chronic renal failure, thyroid disease, hepatic insufficiency, active infection with inflammatory disease other than rheumatoid arthritis and patients with a history of trauma and/or surgery in the last 6 months were excluded from the study. The study was reviewed and approved by the Ethics committee of the Diskapı Yildırım Beyazit Research and Training Hospital (decision no. $17 / 18$ of 3 November 2014) and informed consent was obtained from patients.

All patients underwent a detailed physical examination. Disease activity score (DAS28-ESR) including 28 joints was used to determine disease activity. DAS28-ESR is a scoring system in which the patient's delicate and swollen joint count and global health score are calculated with the sedimentation value (11).

The DAS28-ESR scores below 2.6 were considered as remission, 2.6-3.2 as low disease activity, 3.21-5.1 as middle disease activity and over 5.1 values as high disease activity (12).

Blood samples were taken after 12 hours of fasting. Leukocyte, neutrophil, NLR, MPV and sedimentation were obtained by routine laboratory methods. Blood samples were taken into citrate tubes in order to avoid EDTA-induced changes in platelet volume (12). NLR and MPV were obtained by simple mathematical methods from the same hemogram.

\section{Statistical Analysis}

SPSS statistics program (SPSS for Windows 16.0, Inc., Chicago, IL, USA) was used for statistical analysis. Kolmogorov-Smirnov test was used to test the normal distribution of data. Spearman or Pearson correlation was used to investigate the correlation between MPV, NLR, and demographic and laboratory data. The comparison of the groups was done by t-test. Standard deviation was used to express the average. $\mathrm{p}<0.05$ values were considered statistically significant.

\section{RESULTS}

This study was performed retrospectively between March 2012 and March 2013. The study included a total of 156 patients (137 female (87.7\%) and 19 male (12.2\%)) with rheumatoid arthritis who met the study criteria. The mean age of the patients was $52.15 \pm 12.35$ years (18-85 years).

Mean neutrophil, lymphocyte count and mean platelet volume were $4.52 \pm 1.8710^{3} / \mu \mathrm{L}, 2.21 \pm 0.8810^{3}$ $/ \mu \mathrm{L}$ and $8.84 \pm 0.96 \mathrm{fL}$, respectively.

Demographic data of the patients and their classification according to ${ }^{1}$ DAS28-ESR scores are summarized in Table 1 and Table 2.

A total of 135 patients ( $\mathrm{F}: \mathrm{M}=13: 2)$ had active disease (DAS28-ESR $\geq 2.6)$. 38 patients $(\mathrm{F}: \mathrm{M}=5: 1)$ showed high disease activity (DAS28-ESR > 5.1), 82 patients $(\mathrm{F}: \mathrm{M}=13: 1)$ showed moderate disease activity (DAS28-ESR> 3.2 and 55.1) and 15 patients (F:M=12:1) showed low disease activity. According to DAS28-ESR scores, 21 patients (F:M = 5:2) were in remission (DAS28ESR <2.6).

In the remission group, NLR was $2.30 \pm 0.30$ and in the active disease group, NLR was $2.47 \pm 0.13$. Although NLR was higher in the active disease group than the remission group, this difference was not statistically significant (p:0.616). NLR was $1.98 \pm 0.71,2.26 \pm 1.04$, and $3.11 \pm 2.16$ in patients with low disease activity, moderate disease activity and high disease activity, respectively. There was a statistically significant difference between the groups in terms of NLR (p: 0.030).

In our study, we also investigated the relationship between disease activity and MPV in rheumatoid arthritis. In the remission group and active disease group, MPV was $8.54 \pm 0.78 \mathrm{fl}$ and $8.89 \pm 0.99 \mathrm{fl}$, respectively. Although the MPV was higher in the active disease group, this difference was not significant (p: 0.126). In patients with low disease activity, moderate disease activity and high disease activity, MPV was $9.31 \pm 1.09 \mathrm{fl}, 8.91 \pm 0.98$ $\mathrm{fl}, 8.71 \pm 0.97 \mathrm{fl}$, respectively. Although the MPV was higher in patients with lower disease activity, there was no significant difference between the groups (p: 0.206).

There was a positive correlation between DAS28ESR scores and NLR in patients with active disease ( $\mathrm{r}$ : 0.306, p: 0.001), but no correlation was found between DAS28-ESR scores and MPV (r: -0.151, p:0.08) (Table 3).

\section{DISCUSSION}

In this study, we investigated the relationship between disease activity and NLR and MPV in 156 patients with rheumatoid arthritis determined by DAS28-ESR score. Our results showed that there was a positive correlation between NLR and DAS28-ESR scores in patients with active rheumatoid arthritis. It has been shown that neutrophil lymphocyte ratio, which is a simple, inexpensive and reproducible test result obtained from hemogram results, is an indicator of systemic inflammation in many diseases (13-15) and is closely related to the disease activity markers in inflammatory diseases (16-21).

Mercan et al., Fu H. et al. and Chandrashekara et al. showed that NLR was higher in patients with rheumatoid arthritis compared to patients in remission and correlated with disease activity $(16,21,22)$. Our results are similar to these three studies. At the same time, when we classified patients according to DAS28-ESR scores, we found 
Table I: Comparison of demographic and clinical variables among ${ }^{1}$ DAS28-ESR groups in rheumatoid arthritis patients

\begin{tabular}{|l|l|l|l|}
\hline & DAS28-ESR groups & P-value & \\
\hline & DAS28-ESR $<2.6$ & DAS28-ESR $\geq 2.6$ & \\
& $n: 21$ & $n: 135$ & 0,31 \\
\hline Age & $50.19 \pm 10.36$ & $52.48 \pm 12.64$ & \\
\hline Gender (F:M) ${ }^{2}$ & $5: 2$ & $13: 2$ & 0.02 \\
\hline C-reactive protein, $m g / L$ & $8.26 \pm 9.96$ & $19.46 \pm 29.72$ & 0.01 \\
\hline $\begin{array}{l}\text { Erythrocyte sedimentation rate, } \\
\text { mm/h }\end{array}$ & $22.10 \pm 11.80$ & $42.60 \pm 21.40$ & \\
\hline Neutrophil to lymphocyte ratio & $2.30 \pm 0.30$ & $2.47 \pm 0.13$ & 0.616 \\
\hline Main platelet volume, ${ }^{3} f l$ & $8.54 \pm 0.78$ & $8.89 \pm 0.98$ & 0.126 \\
\hline
\end{tabular}

${ }^{1}$ DAS28-ESR: disease activity score with erythrocyte sedimentation rate, ${ }^{2} \mathrm{~F}:$ female, M: Male, ${ }^{3} \mathrm{fl}:$ femtolitre

Table II: Comparison of demographic and clinical variables among DAS28-ESR groups in rheumatoid arthritis patients

\begin{tabular}{|c|c|c|c|c|c|}
\hline${ }^{1} D A S 28-E S R$ groups & P-value & & & & \\
\hline & $\begin{array}{l}\text { DAS28-ESR }<2.6 \\
\text { (Remission) } n: 21\end{array}$ & $\begin{array}{l}\text { DAS28-ESR } \geq 2.6 \\
\text { and } \leq 3.2 \\
\text { (Low Disease } \\
\text { Activity) } \\
n: 15\end{array}$ & $\begin{array}{l}\text { DAS28-ESR }>3.2 \\
\text { and } \leq 5.1(\text { Mo- } \\
\text { derate Disease } \\
\text { Activity) } n: 87\end{array}$ & $\begin{array}{l}\text { DAS28-ESR }>5.1 \\
\text { (High Disease Activity) } \\
n: 38\end{array}$ & \\
\hline Age & $50.2 \pm 10.36$ & $46.69 \pm 10.42$ & $52.32 \pm 12.19$ & $54.82 \pm 13.89$ & 0.10 \\
\hline Gender $(F: M)^{2}$ & $5: 2$ & $12: 1$ & $13: 1$ & $5: 1$ & 0.07 \\
\hline C-reactive protein, $m g / L$ & $8.26 \pm 9.96$ & $9.58 \pm 10.42$ & $14.41 \pm 20.50$ & $34.03 \pm 43.72$ & 0.01 \\
\hline $\begin{array}{l}\text { Erythrocyte sedimentati- } \\
\text { on rate, } \\
\mathrm{mm} / \mathrm{h}\end{array}$ & $22.10 \pm 11.80$ & $33.54 \pm 21.93$ & $37.79 \pm 17.26$ & $56.37 \pm 23.63$ & 0.01 \\
\hline $\begin{array}{l}\text { Neutrophil to lymphocyte } \\
\text { ratio }\end{array}$ & & $1.98 \pm 0.71$ & $2.26 \pm 1.04$ & $2.26 \pm 1.04$ & 0.030 \\
\hline Main platelet volume, ${ }^{3} \mathrm{fl}$ & & $9.31 \pm 1.09$ & $8.91 \pm 0.98$ & $8.71 \pm 0.97$ & 0.206 \\
\hline
\end{tabular}

${ }^{1}$ DAS28-ESR: disease activity score with erythrocyte sedimentation rate, ${ }^{2} \mathrm{~F}$ : female, M: Male, ${ }^{3}$ fl: femtolitre

Table III: The correlation between NLR and MPV according to DAS28-ESR

\begin{tabular}{|l|l|l|}
\hline & $r$ & $p$ \\
\hline$D A S 28-E S R / N L R^{1}$ & 0.306 & 0.001 \\
\hline$D A S 28-E S R / M P V^{2}$ & -0.151 & 0.080 \\
\hline
\end{tabular}

${ }^{1}$ NLR: Neutrophil lymphocyte ratio, ${ }^{2} \mathrm{MPV}$ : Main Platelet Volume

statistically significant difference in NLR in patients with low disease activity, moderate disease activity and high disease activity. Although Chandrashekara et al reported similar results, they used DAS-CRP instead of DAS-ESR to classify patients, unlike our study.

Neutrophilia, caused when the neutrophils on the vascular wall get into the blood circulation in rheumatoid arthritis progression, and tendency to lymphopenia, due to endogenous steroids increasing in rheumatoid arthritis progression, are well known clinical conditions. We think that this mechanism is the main reason for the correlation between NLR and rheumatoid arthritis activity.

Also in this study, we tried to reveal the relationship between MPV and patients with rheumatoid arthritis. Although we found decreased MPV in subjects with high disease activity, this difference was not statistically significant and was not correlated with disease activity. Small sample size and cross-sectional study plan may have caused this. Conflicting results of systemic inflammation and MPV were reported. In 2011, Gasparyan et al. reported that low inflammation and various risk factors resulted in decreased platelet volume (23). However, Yazıc1 et al. (9) and Talukdar et al. (24) reported that disease activity and inflammatory markers correlated positively with MPV in patients with rheumatoid arthritis. K1sacik et al. reported that patients with rheumatoid arthritis had lower MPV during active disease and increased platelet volume with treatment (25). It is claimed that relatively large and active platelets are accumulated in regions such as joints where inflammation is more dense, and that there is a relatively low volume of platelets remaining, so MPV is measured low (23). 
To the best of our knowledge, our study is one of the rare studies comparing disease activity classified according to DAS28-ESR scores with MPV. Although MPV was lower in patients with high disease activity, this difference was not significant. Anti-coagulation of blood samples, ambient temperature, time to analysis and drugs such as corticosteroids may have affected MPV.

Small sample size and cross-sectional study design were the limitations of our study. Moreover, since the study was conducted only in Turkish population, the results could be affected by racial differences.

As a result, according to our experience in this study; NLR is a useful marker for evaluating disease activity in RA patients. Increased NLR values indicate increased disease activity. However, more comprehensive studies are needed to be able to use MPV values as indicators of disease activity in RA patients.

\section{REFERENCES}

1. Kaushik P, Kaushik R. Diagnosis and management of rheumatoid arthritis. The American journal of medicine 2008;121:e7; author reply e9-10.

2. Wolfe F. Comparative usefulness of C-reactive protein and erythrocyte sedimentation rate in patients with rheumatoid arthritis. The Journal of Rheumatology 1997; 24: 1477-85.

3. Beckham JC, Caldwell DS, Peterson BL, Pippen AM, Currie MS, Keefe FJ, et al. Disease severity in rheumatoid arthritis: relationships of plasma tumor necrosis factor-alpha, soluble interleukin 2-receptor, soluble CD4/CD8 ratio, neopterin, and fibrin D-dimer to traditional severity and functional measures. J Clin Immunol 1992; 12: 353-61.

4. Bhat T, Teli S, Rijal J, Bhat H, Raza M, Khoueiry G, et al. Neutrophil to lymphocyte ratio and cardiovascular diseases: a review. Expert Rev Cardiovasc Ther 2013;11:55-9.

5. Guthrie GJ, Charles KA, Roxburgh CS, Horgan PG, McMillan DC, Clarke SJ. The systemic inflammation-based neutrophil-lymphocyte ratio: experience in patients with cancer. Crit Rev Oncol Hematol 2013;88:218-30.

6. Ahsen A, Ulu MS, Yuksel S, Demir K, Uysal M, Erdogan $\mathrm{M}$, et al. As a new inflammatory marker for familial Mediterranean fever: neutrophil-to-lymphocyte ratio. Inflammation 2013;36:1357-62.

7. Khode V, Sindhur J, Kanbur D, Ruikar K, Nallulwar S. Mean platelet volume and other platelet volume indices in patients with stable coronary artery disease and acute myocardial infarction: A case control study. J Cardiovasc Dis Res 2012;3:272-5.

8. Kurt M, Onal IK, Sayilir AY, Beyazit Y, Oztas E, Kekilli M, et al. The role of mean platelet volume in the diagnosis of hepatocellular carcinoma in patients with chronic liver disease. Hepato-gastroenterology 2012;59:1580-2.

9. Yazici S, Yazici M, Erer B, Calik Y, Ozhan H, et al. The platelet indices in patients with rheumatoid arth- ritis: mean platelet volume reflects disease activity. Platelets 2010;21:122-5.

10. Jurcut C, Jurcut R, Caraiola S, Niţescu D, Mihai C, Baicuş A, et al. Platelet histogram indices and cardiovascular disease in patients with rheumatoid arthritis. Rom J Intern Med 2010;48:51-5.

11. Prevoo ML, van 't Hof MA, Kuper HH, van Leeuwen MA, van de Putte LB, van Riel PL. Modified disease activity scores that include twenty-eight-joint counts. Development and validation in a prospective longitudinal study of patients with rheumatoid arthritis. Arthritis and Rrheumatism 1995;38:44-8.

12. Balsa A, Carmona L, Gonzalez-Alvaro I, Belmonte MA, Tena X, Sanmarti R. Value of Disease Activity Score 28 (DAS28) and DAS28-3 compared to American College of Rheumatology-defined remission in rheumatoid arthritis. J Rheumatol 2004;31:40-6.

13. Tamhane UU, Aneja S, Montgomery D, Rogers EK, Eagle KA, Gurm HS. Association between admission neutrophil to lymphocyte ratio and outcomes in patients with acute coronary syndrome. Am J Cardiol 2008;102:653-7.

14. Ozturk ZA, Kuyumcu ME, Yesil Y, Savas E, Yıldız $\mathrm{H}$, Kepekçi $\mathrm{Y}$, et al. Is there a link between neutrophil-lymphocyte ratio and microvascular complications in geriatric diabetic patients? J Endocrinol Invest 2013;36:593-9.

15. Kuyumcu ME, Yesil Y, Ozturk ZA, Kizilarslanoğlu C, Etgül S, Halil M, et al. The evaluation of neutrophil-lymphocyte ratio in Alzheimer's disease. Dement Geriatr Cogn Disord 2012;34:69-74.

16. Mercan R, Bitik B, Tufan A, Bozbulut UB, Atas N, Ozturk MA, et al. The Association Between Neutrophil/Lymphocyte Ratio and Disease Activity in Rheumatoid Arthritis and Ankylosing Spondylitis. J Clin Lab Anal 2016;30:597-601.

17. Yang $\mathrm{W}$, Wang $\mathrm{X}$, Zhang $\mathrm{W}$, Ying $\mathrm{H}, \mathrm{Xu} \mathrm{Y}$, Zhang J, et al. Neutrophil-lymphocyte ratio and platelet-lymphocyte ratio are 2 new inflammatory markers associated with pulmonary involvement and disease activity in patients with dermatomyositis. Clin Chim Acta 2017;465:11-16.

18. Kucuk A, Uslu AU, Ugan Y, Bagcaci S, Karahan AY, Akarmut A, et al. Neutrophil-to-lymphocyte ratio is involved in the severity of ankylosing spondylitis. Bratisl Lek Listy 2015;116:722-5.

19. Qin B, Ma N, Tang Q, Wei T, Yang M, Fu H, et al. Neutrophil to lymphocyte ratio (NLR) and platelet to lymphocyte ratio (PLR) were useful markers in assessment of inflammatory response and disease activity in SLE patients. Mod Rheumatol 2016;26:3726.

20. Uslu AU, Kucuk A, Sahin A, Ugan Y, Y1lmaz R, et al. Two new inflammatory markers associated with Disease Activity Score-28 in patients with rheumatoid arthritis: neutrophil-lymphocyte ratio and platelet-lymphocyte ratio. Int J Rheum Dis 2015;18:7315. 
21. Fu H, Qin B, Hu Z, Ma N, Yang M, Wei T, et al. Neutrophil- and platelet-to-lymphocyte ratios are correlated with disease activity in rheumatoid arthritis. Clin Lab 2015;61:269-73.

22. Chandrashekara S, Mukhtar Ahmad M, Renuka P, Anupama KR, Renuka K. Characterization of neutrophil-to-lymphocyte ratio as a measure of inflammation in rheumatoid arthritis. Int $\mathrm{J}$ Rheumat Dis 2017;20:1457-1467.

23. Gasparyan AY, Ayvazyan L, Mikhailidis DP, Kitas GD. Mean platelet volume: a link between thrombosis and inflammation? Curr Pharm Des. 2011;17:4758.
24. Talukdar M, Barui G, Adhikari A, Karmakar R, Ghosh UC, Das TK. A Study on association between common haematological parameters and disease activity in rheumatoid arthritis. J Clin Diag Res: 2017;11:Ec01-ec04.

25. Kisacik B, Tufan A, Kalyoncu U, Karadag O, Akdogan A, Ozturk MA, et al. Mean platelet volume (MPV) as an inflammatory marker in ankylosing spondylitis and rheumatoid arthritis. Joint Bone Spine 2008;75:291-4. 